\title{
Assessment of Competitiveness Factors of an Agent of the Financial Environment: Methodology and Comparative Analysis
}

\author{
Elvira Sitnikova*, Tatyana Kolmykova, Irina Tretyakova, and Darya Lobacheva \\ Southwest State University, Kursk, Russian Federation
}

\begin{abstract}
The functioning of the banking sector of the economy in the world is characterized by a decrease in its capital intensity due to a decrease in the concentration of foreign capital, a deterioration in the quality of the loan portfolio, an outflow of urgent deposit resources and the receipt of significant losses by banking institutions during the COVID-19 pandemic. Taking into account the current trends in the spread of the virus, the development and implementation of fundamentally new approaches to anticrisis management in the banking sector of both the world economy and Russia is of great importance today. The COVID-19 pandemic came as a big shock to the global and European economies. While banks are not hit by the pandemic as directly as other retail institutions, they are in the public eye as they provide funding to corporations and individuals. Their stability is crucial for maintaining the efficiency of the entire economic system, not only of a particular country, but also of the world. Currently, the need for a comprehensive study of the competitiveness of a commercial bank is determined by the objective modern conditions of the life of banks operating in a competitive environment. The article proposes the author's methodology for assessing the competitiveness of a commercial bank, which includes five groups of indicators, which makes it possible to identify not only problematic, but also stable areas of activity. The proposed method for calculating the integral indicator for assessing the competitiveness of a commercial bank has been tested on the example of Russian Agricultural Bank and Sberbank, and a set of measures has been developed to increase the level of competitiveness of a commercial bank.
\end{abstract}

\section{Introduction}

A modern system for assessing the competitiveness of a commercial bank should be based on integral, complex indicators. The need for the formation of integral assessments of the competitiveness of a credit institution arises due to the fact that private indicators, describing certain phenomena, do not allow obtaining a comprehensive idea of the level of development and positions of a commercial bank. Another reason for the need to form integral assessments is the desire to understand the processes occurring in a credit institution and their causes. Only by analyzing a set of private indicators, it is possible to identify the reasons for the

${ }^{*}$ Corresponding author: 0209elvira@mail.ru 
growth or decrease in the size of the resource base, the level of return on assets, profitability, and, ultimately, the financial position of the credit institution $[1,2,3,4]$.

\section{Methodology for a comprehensive assessment of the competitiveness of a commercial bank}

The methodology for assessing the level of competitiveness of a commercial bank includes five components, each of which includes the corresponding groups of indicators. Table 1 shows the indicators for assessing the level of competitiveness and the method of their calculation.

Table 1. Main indicators for assessing the level of competitiveness of the bank

\begin{tabular}{|c|c|}
\hline Indicator & Calculation formula \\
\hline \multicolumn{2}{|c|}{1 Indicators characterizing the level of asset quality of a commercial bank $\left(\mathrm{CCB}_{\mathrm{A}}\right)$ : } \\
\hline $\begin{array}{llll}\text { Earning } & \text { asset level ratio } \\
\left(\mathrm{CCB}_{\mathrm{A} 1}\right) & & & \\
\end{array}$ & $\begin{array}{l}\text { ratio of working assets to total assets of a commercial } \\
\text { bank }\end{array}$ \\
\hline $\begin{array}{l}\text { Highly liquid assets to } \\
\text { liabilities ratio }\left(\mathrm{CCB}_{\mathrm{A} 2}\right)\end{array}$ & $\begin{array}{l}\text { ratio of highly liquid assets to funds raised by a } \\
\text { commercial bank }\end{array}$ \\
\hline Credit activity ratio $\left(\mathrm{CCB}_{\mathrm{A} 3}\right)$ & the ratio of net debt to bank assets \\
\hline \multicolumn{2}{|c|}{ 2. Capital Adequacy Indicators of a Commercial Bank $\left(\mathrm{CCB}_{\mathrm{C}}\right)$} \\
\hline $\begin{array}{l}\text { Total capital adequacy ratio } \\
\left(\mathrm{CCB}_{\mathrm{C} 1}\right)\end{array}$ & the ratio of sources of own funds to total liabilities \\
\hline $\begin{array}{l}\text { Equity capitalization earnings } \\
\text { ratio }\left(\mathrm{CCB}_{\mathrm{C} 2}\right)\end{array}$ & $\begin{array}{l}\text { the ratio of the commercial bank's own resources to the } \\
\text { funds contributed by the founders }\end{array}$ \\
\hline $\begin{array}{l}\text { Equity capital efficiency ratio } \\
\left(\mathrm{CCB}_{\mathrm{C} 3}\right)\end{array}$ & $\begin{array}{l}\text { the ratio of the profit of a commercial bank to its own } \\
\text { funds }\end{array}$ \\
\hline \multicolumn{2}{|c|}{ 3. Indicators characterizing the level of liquidity of a commercial bank $\left(\mathrm{CCB}_{\mathrm{L}}\right)$} \\
\hline $\begin{array}{lll}\text { Absolute liquidity } & \text { ratio } \\
\left(\mathrm{CCB}_{\mathrm{L} 1}\right)\end{array}$ & the ratio of cash to bank liabilities \\
\hline Total liquidity ratio $\left(\mathrm{CCB}_{\mathrm{L} 2}\right)$ & the ratio of a bank's assets to its liabilities \\
\hline \multicolumn{2}{|c|}{ 4. Indicators characterizing the level of activity intensity $\left(\mathrm{CCB}_{\mathrm{AI}}\right)$} \\
\hline $\begin{array}{lll}\text { Investment level ratio } \\
\left(\mathrm{CCB}_{\mathrm{AII}}\right)\end{array}$ & $\begin{array}{l}\text { the ratio of the volume of investments in securities to the } \\
\text { bank's assets }\end{array}$ \\
\hline $\begin{array}{lrl}\text { Investment level } & \text { ratio in } \\
\text { affiliates }\left(\mathrm{CCB}_{\mathrm{AI} 2}\right) & & \\
\end{array}$ & $\begin{array}{l}\text { the ratio of the volume of investments in subsidiaries and } \\
\text { affiliates to assets }\end{array}$ \\
\hline \multicolumn{2}{|c|}{ 5. Indicators for assessing the level of riskiness $\left(\mathrm{CCB}_{\mathrm{R}}\right)$} \\
\hline $\begin{array}{ll}\text { Risk level coefficient } \\
\left(\mathrm{CCB}_{\mathrm{R} 1}\right)\end{array}$ & $\begin{array}{l}\text { the ratio of all liabilities of a commercial bank to working } \\
\text { assets }\end{array}$ \\
\hline Doubtful debt ratio $\left(\mathrm{CCB}_{\mathrm{R} 2}\right)$ & $\begin{array}{l}\text { ratio of overdue debt to the volume of loans, deposits and } \\
\text { other placed funds }\end{array}$ \\
\hline Risk immunity ratio $\left(\mathrm{CCB}_{\mathrm{R} 3}\right)$ & $\begin{array}{l}\text { the ratio of the amount of profit of a credit institution of } \\
\text { previous years to income-generating assets }\end{array}$ \\
\hline
\end{tabular}

The aggregate indicator of each component of the indicator (asset quality; capital adequacy; liquidity; investment activity; riskiness) characterizing the competitiveness of a commercial bank is determined as the geometric mean of the products, respectively: indicators characterizing the level of asset quality of a commercial bank; indicators of the level of capital adequacy of a commercial bank; indicators characterizing the level of liquidity of a commercial bank; indicators characterizing the level of activity intensity; indicators for assessing the level of riskiness. 
The value of the integral indicator for assessing the competitiveness of a commercial bank makes it possible to assess the competitive position of the bank. The result of this integral indicator makes it possible to determine the type of competitive position of a commercial bank in accordance with the scale (Table 2).

Table 2. Characteristics of competitive positions in accordance with the integral indicator of competitiveness

\begin{tabular}{|c|l|}
\hline $\begin{array}{c}\text { The value of the integral indicator of } \\
\text { competitiveness }\end{array}$ & \multicolumn{1}{c|}{ A type } \\
\hline $0,02-0,08$ & Low competitiveness \\
\hline $0,09-0,15$ & Average competitiveness \\
\hline $0,16-0,20$ (and more) & High competitiveness \\
\hline
\end{tabular}

The proposed system is universal, i.e. applicable to all commercial banks, regardless of the organizational and legal form and policy of conducting banking business.

Thus, as a result of the study, a methodology for calculating the integral indicator for assessing the competitiveness of a commercial bank has been developed. This technique is presented in the form of sequential actions in order to determine and calculate the integrated indicator using indicators that characterize reliability, liquidity, efficiency. Determination of the competitive position of a commercial bank will allow to identify the most problematic and most stable areas of activity.

\section{Approbation of the methodology for assessing the competitiveness of a commercial bank}

The authors monitored the competitiveness of commercial banks in the context of indicators characterizing the financial condition of credit institutions.

In terms of assets, PJSC Sberbank is in the lead, the value of which as of 01.01.2020 is 28894.5 billion rubles. VTB Bank ranks second, significantly behind the leader in terms of net assets. Russian Agricultural Bank ranks sixth [5].

According to the indicator «Net profit» the leader is Sberbank. The net profit of most banks in 2019 has a positive trend, except for VTB Bank (a decrease of 18.9\%) and AlfaBank (a decrease of 53.9\%). Russian Agricultural Bank in 2019 takes 38th place, the volume of net profit as of 01.01.2020. is 4865.8 million rubles. The bank's net profit increased by $88.5 \%$ compared to 2018 .

The amount of equity capital tends to increase. Russian Agricultural Bank in terms of equity capital takes 4 th place.

In 2019, Russian Agricultural Bank ranks 4th in terms of the "Volume of deposits of Russian banks»), the volume of deposits in the bank increased by $8.7 \%[6,7]$.

Russian Agricultural Bank in 2019 ranks 4th in this indicator, significantly inferior in terms of volume to the top three. The volume of deposits in Russian Agricultural Bank increased by $14.3 \%$.

Thus, the most reliable bank in Russia in terms of the analyzed financial indicators is unambiguously Sberbank.

Let's assess competitiveness using an integral indicator. The main indicators for calculating the integral indicator for assessing the competitiveness of Sberbank and Russian Agricultural Bank are presented in Table 3. 
Table 3. Components for calculating the integral indicator of assessing the competitiveness of Sberbank and Russian Agricultural Bank

\begin{tabular}{|c|c|c|c|c|}
\hline Indicator & 2018 & 2019 & 2018 & 2019 \\
\hline \multicolumn{5}{|c|}{ 1. Indicators characterizing the level of asset quality of a commercial bank $\left(\mathrm{CCB}_{\mathrm{A}}\right)$} \\
\hline & \multicolumn{2}{|c|}{ Sberbank } & \multicolumn{2}{|c|}{ Russian Agricultural Bank } \\
\hline $\begin{array}{l}\text { Earning asset level ratio } \\
\left(\mathrm{CCB}_{\mathrm{A} 1}\right)\end{array}$ & 0.855 & 0.813 & 0.844 & 0.773 \\
\hline $\begin{array}{l}\text { Highly liquid assets to } \\
\text { liabilities ratio }\left(\mathrm{CCB}_{\mathrm{A} 2}\right)\end{array}$ & 0.029 & 0.028 & 0.049 & 0.019 \\
\hline $\begin{array}{lll}\begin{array}{l}\text { Credit } \\
\left(\mathrm{CCB}_{\mathrm{A} 3}\right)\end{array} & \text { activity } & \text { ratio } \\
\end{array}$ & 0.749 & 0.696 & 0.659 & 0.757 \\
\hline \multicolumn{5}{|c|}{ 2. Capital Adequacy Indicators of a Commercial Bank $\left(\mathrm{CCB}_{\mathrm{C}}\right)$ : } \\
\hline & \multicolumn{2}{|c|}{ Sberbank } & \multicolumn{2}{|c|}{ Russian Agricultural Bank } \\
\hline $\begin{array}{l}\text { Total capital adequacy ratio } \\
\left(\mathrm{CCB}_{\mathrm{C} 1}\right)\end{array}$ & 0.141 & 0.159 & 0.094 & 0.054 \\
\hline $\begin{array}{l}\text { Equity capitalization } \\
\text { earnings ratio }\left(\mathrm{CCB}_{\mathrm{C} 2}\right)\end{array}$ & 56.084 & 65.005 & 0.763 & 0.396 \\
\hline $\begin{array}{l}\text { Equity capital efficiency } \\
\text { ratio }\left(\mathrm{CCB}_{\mathrm{C} 3}\right)\end{array}$ & 0.206 & 0.194 & 0.007 & 0.024 \\
\hline \multicolumn{5}{|c|}{ 3. Indicators characterizing the level of liquidity of a commercial bank $\left(\mathrm{CCB}_{\mathrm{L}}\right)$ : } \\
\hline & \multicolumn{2}{|c|}{ Sberbank } & \multicolumn{2}{|c|}{ Russian Agricultural Bank } \\
\hline $\begin{array}{lll}\text { Absolute liquidity ratio } \\
\left(\mathrm{CCB}_{\mathrm{L} 1}\right)\end{array}$ & 0.029 & 0.028 & 0.049 & 0.019 \\
\hline $\begin{array}{lll}\text { Total liquidity ratio } \\
\left(\mathrm{CCB}_{\mathrm{L} 2}\right)\end{array}$ & 0.133 & 0.207 & 0.994 & 0.957 \\
\hline \multicolumn{5}{|c|}{ 4. Indicators characterizing the level of activity intensity $\left(\mathrm{CCB}_{\mathrm{AI}}\right)$} \\
\hline & \multicolumn{2}{|c|}{ Sberbank } & \multicolumn{2}{|c|}{ Russian Agricultural Bank } \\
\hline $\begin{array}{lll}\text { Investment } & \text { level } & \text { ratio } \\
\left(\mathrm{CCB}_{\mathrm{AI} 1}\right) & & \end{array}$ & 0.903 & 0.174 & 0.158 & 0.126 \\
\hline $\begin{array}{l}\text { Investment level ratio in } \\
\text { affiliates }\left(\mathrm{CCB}_{\mathrm{AI} 2}\right)\end{array}$ & 0.029 & 0.027 & 0.009 & 0.019 \\
\hline \multicolumn{5}{|c|}{ 5. Indicators for assessing the level of riskiness $\left(\mathrm{CCB}_{\mathrm{R}}\right)$} \\
\hline & \multicolumn{2}{|c|}{ Sberbank } & \multicolumn{2}{|c|}{ Russian Agricultural Bank } \\
\hline $\begin{array}{ll}\begin{array}{l}\text { Risk level coefficient } \\
\left(\mathrm{CCB}_{\mathrm{R} 1}\right)\end{array} & \\
\end{array}$ & 1.004 & 1.031 & 1.073 & 1.224 \\
\hline $\begin{array}{lll}\begin{array}{l}\text { Doubtful } \\
\left(\mathrm{CCB}_{\mathrm{R} 2}\right)\end{array} & \text { debt } & \text { ratio } \\
\end{array}$ & 0.283 & 0.363 & 0.245 & 0.392 \\
\hline $\begin{array}{ll}\text { Risk immunity ratio } \\
\left(\mathrm{CCB}_{\mathrm{R} 3}\right)\end{array}$ & 0.032 & 0.178 & 0.001 & 0.001 \\
\hline
\end{tabular}

Integral indicators and the aggregate integral indicator for assessing the competitiveness of Sberbank and Russian Agricultural Bank are presented in Table 4. 
Table 4. Integral indicators and the aggregate integral indicator for assessing the competitiveness of Sberbank and Russian Agricultural Bank.

\begin{tabular}{|l|c|c|c|c|}
\hline & \multicolumn{2}{|c|}{ Sberbank } & \multicolumn{2}{c|}{ Russian Agricultural Bank } \\
\hline \multicolumn{1}{|c|}{ Indicator Asset Quality } & 2018 & 2019 & 2018 & 2019 \\
\hline $\begin{array}{l}\text { Aggregate } \\
\text { Indicator }\end{array}$ & 0.265 & 0.251 & 0.306 & 0.223 \\
\hline $\begin{array}{l}\text { Aggregate Capital Adequacy } \\
\text { Indicator }\end{array}$ & 1.176 & 1.261 & 0.079 & 0.080 \\
\hline Aggregate liquidity indicator & 0.062 & 0.076 & 0,221 & 0.135 \\
\hline $\begin{array}{l}\text { Aggregate indicator of } \\
\text { investment activity }\end{array}$ & 0.161 & 0.068 & 0.038 & 0.048 \\
\hline Aggregate risk indicator indicator & 0.209 & 0.405 & 0.064 & 0.078 \\
\hline $\begin{array}{l}\text { Aggregate integral ingetiveness } \\
\text { for assessing competitiven }\end{array}$ & 0.209 & 0.231 & 0.105 & 0.098 \\
\hline
\end{tabular}

The aggregate integral indicator of Russian Agricultural Bank is 0.105 in 2018, and 0.098 in 2019. Consequently, according to this indicator, we will determine the type of competitive position of Russian Agricultural Bank. In 2017, Russian Agricultural Bank has low competitiveness, and in 2019 - average competitiveness. As a result of the typology, it can be concluded that in 2018 Russian Agricultural Bank ensured the fulfillment of the main regulatory performance indicators, however, it has a limited resource base, which translates into a low coverage of the banking services market by the bank and a low diversification of the client base. Those. the bank's activity can be characterized as close in terms of indicators to low-competitiveness.

The cumulative integral indicator of Sberbank in 2018 is 0.209 , and in $2019-0.231$. There is a positive trend in this indicator. Consequently, according to this indicator, Sberbank is highly competitive. Thus, Sberbank carries out effective activities, there is the necessary amount of the resource base to meet all the needs of customers.

\section{Conclusions and recommendations}

Let's highlight the main directions of increasing the competitiveness of Russian commercial banks:

- development of banking infrastructure (compliance of the regulatory and legal framework with modern development conditions, improvement of subsystems of scientific, informational and methodological support, creation of conditions for the openness of the banking services market);

- increasing awareness and financial literacy of bank clients (primarily individuals);

- increased attention of commercial banks to strategic planning;

- development of effective communication skills, sales skills, i.e. shaping a marketing mindset among bank employees;

- introduction of unified standards of banking culture and business ethics both at the intrabank level and in relation to external counterparties;

- stimulation of the accelerated introduction of modern banking technologies [8,9].

Thus, after analyzing the data and considering the rating of the most successful, large and demanded banks, a constant tendency towards leadership in all areas of Sberbank was revealed. 


\section{References}

1. S.S. Velichko Bank competitiveness: theoretical analysis, Financial journal, 1, 135-144 (2018)

2. L.E. Zernova Analysis of the competitiveness of a commercial bank, Modern Science,41, 88-93 (2020)

3. E.V. Sitnikova, T.S. Kolmykova, E.O. Astapenko, E.A. Grivachev An Assessment of Commercial Banks' Financial Sustainability, Lecture Notes in Networks and Systems, 115, 370-378 (2020)

4. I.N. Tretyakova, E.V. Sitnikova The industrial complex of the region: lending trends and development prospects (based on materials from the Kursk region, Education. Science. Scientific staff, 1, 141-144 (2015)

5. I. Tretyakova, E. Sitnikova. International financial processes influence on the retail lending market in Russia development, Економічний часопис-XXI, 3-4-1 (157), 100-102 (2016)

6. T. Kolmykova, E. Merzlyakova Human role in the modern robotic reproduction development, Economic Annals-XXI, 180 (11-12), 183-190 (2019)

7. I.M. Sinyaev Competitiveness Problems of the Commercial Bank of Russia, Marketing and Logistics, 6(26), 41-51(2019)

8. T. Kolmykova, E. Merzlyakova, V. Bredikhin, T. Tolstykh, O. Ovchinnikova. Problems of Formation of Perspective Growth Points of High-Tech Productions, Advances in Intelligent Systems and Computing, 469-475 (2018)

9. T. Kolmykova, E. Merzlyakova, B. Preobrazhensky, N. Serebryakova Problems of investment support for innovative development: the 33rd International Business Information Management Association Conference, IBIMA «Education Excellence and Innovation Management through Vision 2020», 2199-2204 (2019) 